\title{
In the maw of the Ouroboros: an analysis of scientific literacy and democracy
}

\author{
Lars Bang1 ${ }^{1}$
}

Received: 24 November 2014/ Accepted: 10 February 2017/Published online: 3 October 2017

(C) The Author(s) 2017. This article is an open access publication

\begin{abstract}
This paper explores the concept of scientific literacy through its relation to democracy and citizenship. Scientific literacy has received international attention in the twenty-first century as demonstrated by the Programme for International Student Assessment survey of 2006. It is no longer just a concept but has become a stated and testable outcome in the science education research community. This paper problematizes the 'marriage' between scientific literacy and democracy, particularly the idea that scientific literacy is a presupposed necessity to proper citizenship and awareness of the role of science in modern society. A perusal of the science education literature can provide a history of scientific literacy, as it exists as a research category. Through Gilles Deleuze's notion of the Dogmatic Image of Thought and its relation to a Spinozist understanding of individuation/Becoming, it is argued that scientific literacy is not a recent invention and is problematic in its relation to democracy. This article is thus intended to act more as vehicle to move, stimulate and dramatize thought and potentially reconceptualise scientific literacy, than a comprehensive historical analysis. The concept of scientific literacy has undergone specific transformations in the last two centuries and has been enacted in different manifestations throughout modernity. Here the analysis draws upon Deleuze's reading of Michel Foucault and the notion of the Diagram related to Foucault's oeuvre, and is specifically using Foucault's notion of rationalities as actualized threads or clusters of discourse. The obvious link between science and democracy is an effect of specific rationalities within the epistemological field of science, rather than intrinsic, essential characteristics of science or scientific literacy. There is nothing intrinsic in its function for democracy. Through a case study of the work of Charles W. Eliot and Herbert Spencer and the modern enactment of scientific literacy in contemporary science education, this paper shows the cultural and historical contingencies on which the relation between scientific literacy and democracy has been constructed through a rationality this
\end{abstract}

Lead editor: Bronwen Cowie

Lars Bang

lbj@learning.aau.dk; 1.jensen@mmu.ac.uk

1 Education and Social Research Institute, STEM Education, Manchester Metropolitan University, Manchester, UK 
article calls the Man of Science. The mythical Ouroboros will be used as a Fresh Image of Thought to explore the movements and folds within the discursive formation of Scientific Literacy, the rationality of the Man of Science, and their relation to democracy.

Keywords Scientific literacy · Democracy $\cdot$ Deleuze $\cdot$ Foucault $\cdot$ Dramatization

The greatest striving of the mind, and its greatest virtue is understanding things by the third knowledge.

(Spinoza 1996)

\section{Clarifying our understanding of scientific literacy}

There is a need to clarify our understanding of what scientific literacy is, or perhaps more precisely what scientific literacy can do. Scientific literacy has in science education research been forwarded as a myth (Shamos 1995), as a difference between scientific literacy and science literacy (Roberts 2007), as citizen science (Roth and Barton 2004) and many other shapes and forms. It seems as if one of the very frames of science education is quite hard to pin down and enunciate adequately. Scientific literacy will here be rethought through the philosophical concepts of Being and Becoming, and through the works of the philosophers Gilles Deleuze and Benedict Spinoza. Scientific literacy will be recast in an Ouroboros-diagram and 'non-image', enunciating the arbitrary nature of the connection between democracy/citizenship, instead reconnecting scientific literacy to individuation. In other words, scientific literacy has historically been connected to a Dogmatic Image of Thought, and the aim is here to outline how one can 'free' the concept of scientific literacy potentially reaching a more adequate conceptualization.

\section{A brief diagnosis of scientific literacy}

Scientific literacy has historically and in contemporary science education research (Linder, Östman, Roberts, Wickman, Ericksen, and MacKinnon 2010) been associated with a particular expression of desired Being and identity connected to the notion of modern enlightenment (Popkewitz 2008). For instance we see an intention and desire framed in OECD's policy regarding scientific literacy, concerning a higher percentage of the population being scientific literate, which resonates through connected policies to scientific literacy / interest in science (OECD 2006). A desired relation is thus actualized in curriculum and policies between Being-Scientific, that is behaving, acting and thinking in scientific terms, and Being-Scientist, that is behaving, acting and thinking like a true scientist; where one (Being-Scientist) is seen as the effect of the other (Being-Scientific). The proposed rationality suggests a higher degree of chance of a student pursuing a career in Science, through the introduction and nurturing of a specific scientific line of thought in the educational system. In other words, an intention of fostering a specific being, ie. Homo empiricus (Bang 2014). Scientific literacy is one of the seeds Education/the State wishes to sow to produce scientists through enacting an alchemy of the mind (Popkewitz 2004) or more generally through various apparatus (Bazzul 2012), so the best students become enculturated in the ways of science. Producing a specific form of Being (Being-Scientific/ 
Being-Scientist), legislated towards a desired subjectivity, enacts a specific kind of subjectivation (Bang and Valero 2014), enacted in the form of Being-blueprints, through an educational moulding of Mind and Morale/Morality, enforcing the unforeseeable and restricting thought. The particular rationality connected to Being-Scientific/Being-Scientist is here called The Man of Science. This specific moulding thus ultimately has the intention to stifle and restrict the chaotic Becoming. One of these contemporary forms of subjectivation is PISA's modern test regime and how it enunciates a specific testable scientific literacy connected to democracy/citizenship.

Deleuze revealed a particular failing in Western thinking and history of philosophy, a Dogmatic Image of Thought build upon a misconception of thought stated in terms of Being and identity (Deleuze 1994). The Dogmatic Image of Thought is related to the legacy of Rene Descartes and how this image ultimately limits our understanding of consciousness, thinking and understanding. This Dogmatic Image of Thought is similarly reproduced in the history of science, reproducing an inherently flawed Cartesian scientific reason. The 'individual in intensity' (Deleuze 1994, p. 259), one of Deleuze's expressions for individuation, is 'produced' in terms of Becoming, not moulded toward a specific Being, and the above ideal blueprint of Being-Scientific/Being-Scientist is thus flawed from the very ground up. Scientific knowledge, knowledge regarding nature in the Spinozist sense, has a fundamental role in that continuous process. Spinoza's notion of the continuous production of knowledge and understanding (Wilson 1995) and how it is linked to the basic affectations of the body is here the crux upon which Deleuze's Fresh Image of Thought turns. To summarize the brief diagnosis of scientific literacy the concept of scientific literacy is an inadequate idea in Spinozist/Deleuzian terms without connection to this process of Becoming and continuous unfolding and reconnection of knowledge (here the Ouroboros). A reconceptualization is thus necessary to drag the concept of scientific literacy from its Platonic heights to Earth and expose the necessary monster of the Ouroboros (the Abstract Machine) within. Scientific Literacy's arbitrary relation with Democracy through a notion of Citizenship serves as a vehicle, a ontological crack, to expose the inadequacy of scientific literacy posited in a Dogmatic Image of Thought, and to reconceptualise/reaffirm the concept as a whole in a new Image of Thought, or exactly thought without an image (Deleuze 1994), including the monstrous Abstract Machine of the Ouroboros.

\section{The image of the Ouroboros}

To reach a new Image of Thought of scientific literacy adequately connected to Becoming and knowledge/understanding, this article draws upon the image of the Ouroboros as an Image of Thought of the monstrous dual nature of the rationalities within scientific literacy (the Diagram), which is exemplified and enunciated in the section 'A vivisection of Scientific Literacy_exposing the Ouroboros'. The Ouroboros is, in Deleuze's terms, a Diagram of Scientific Literacy (Deleuze 1986), enveloping a specific Abstract Machine (Deleuze and Guattari 1987) generating and reconnecting rationalities of thought (BeingScientific and Being-Scientist). Deleuze and Guattari sometimes use assemblage as another word for the Diagram (Deleuze and Guattari 1983), enunciating the desirous connections always and already part of the assemblage (Deleuze 1994). I will use the word Diagram here to enunciate the Foucauldian aspect of the analysis and problematic.

The Ouroboros is a mythological creature connected to notions of greed, appetite, selfdestruction, and endlessness and Carl G. Jung (1980) associated it with his notion of 
alchemy and related it to the transformation and genesis of the self. Norse mythology called it the Midgard Serpent, the worm/serpent encircling the whole world, destined to slay Thor in Ragnarök. The Ouroboros has surfaced in many places, with different meanings and connotations, but always associated with change and alchemy (Lindsay 1970). The use of a fresh Image of Thought associated with the ancient one is inspired by Friedrich Nietzsche's use of such images as Ariadne and Dionysus (Nietzsche 2005) and is not to indicate a new symbolism, but a necessary eternal return of the monstrous and, in particular, to release the Becoming related to it from a Cartesian understanding of knowledge and Cogito, the Dogmatic Image of Thought (Deleuze 1994).

The Ouroboros is articulated and conjured generally from the historic development of scientific literacy (knowledge regarding nature) and specifically from PISA06, Charles Eliot, and Herbert Spencer. First, however, it is necessary to outline the methodology, the specific vivisection of the history of scientific literacy and the 'history of the present' (Foucault 1995, p. 31), before the Ouroboros can be connected to specific historical instances of Herbert Spencer, Charles W. Eliot, and how they connect to PISA06, through specific desired templates of Being-Scientist and Being-Scientific.

\section{A vivisection of scientific literacy: exposing the Ouroboros}

A new cut is utilized to expose scientific literacy and the specific vivisection employed refers to the specific Foucauldian and Deleuzian cut and reconceptualization of the Dogmatic Image of Thought and its related concepts. This is very much an active movement of thought - hence the term vivisection - and it entails cutting up live formations of discourse, opening and dissecting thinkers, and so forth. In other words, it is a cut on the surface of thought, related to certain method of dramatization (Deleuze 2004b) and Foucauldian interpretive analytics (Dreyfus and Rabinow 1983). The dramatization evoked here is based on Deleuze's method of dramatization related to actualizing the Idea (here scientific literacy): "Through dramatization, the Idea is incarnated or actualized, it differentiates itself." (Deleuze 2004b, p. 94). The actualization of scientific literacy is being traced in three instances or events: Herbert Spencer's scientism, Eliot's ideas regarding reform of the American science curriculum and education and finally PISA06.

Scientific literacy is a concept involving at least two specific aspects: (1) a specific desired scientific Mind/Cogito linked to Being-Scientific (Bang 2014), which is contemporarily explained as scientific competencies, skills, awareness, and so forth (Hurd 2002), and (2) a modicum of scientific knowledge, both of science itself and science's role outside of itself (society, the State, social perspectives, etc.) (Laugksch 2000). These aspects can be exposed and understood using Foucault's notion of rationalities (Foucault 1972). These rationalities are actualized as the very framework, membranes, and corners of the discursive formation (Foucault 1972, pp. 41-42) of scientific literacy connecting it with other concepts and Diagrams.

Deleuze (1986) used three concepts regarding Foucault's specific methodology and two in particular are outlined as a topology in this vivisection: the notions of the Archive, the Map, and the Diagram. The Archive is linked to the particular actualized discursive formation examined in the writing of PISA06, Spencer, and Eliot-that is, texts and statements. The Map is connected to their spread-science education practices, curricula, and other instances - an aspect only briefly touched upon here. Finally, the Diagram, the coiling abstract machine of the Ouroboros, represents a particular relation of forces that 
constitutes Power and these manifest in a given epoch and subsequently change and shift in time. As Deleuze wrote:

What can we call such a new informal dimension? On one occasion Foucault gives it its most precise name: it is a 'diagram', that is to say a 'functioning, abstracted from any obstacle ... or friction [and which] must be detached from any specific use'. The diagram is no longer an auditory or visual archive but a map, a cartography that is coextensive with the whole social field. It is an abstract machine. It is defined by its informal functions and matter and in terms of form makes no distinction between content and expression, a discursive formation and a non-discursive formation. It is a machine that is almost blind and mute, even though it makes others see and speak. (Deleuze 1986, p. 34, my emphasis)

The Diagram(s) are a multiplicity of heterogeneous relations in the social field(s). There is thus a diagram of science education and, more specifically, of scientific literacy, of forces and Power, that serves as the condition of thought and un-thought in science education. Diagrams influence diagrams, meaning that the diagram of late capitalism (or similar epochal diagrams) and its specific axiomatic flows of deterritorialization and reterritorialization (Deleuze and Guattari 1983) (colonizing and remaking everything according to the logic of capitalism) influence and connect with the diagram of scientific literacy:

The diagram or abstract machine is the map of relations between forces, a map of destiny, or intensity, which proceeds by primary non-localizable relations and at every moment passes through every point, 'or rather in every relation from one point to another'. (Deleuze 1986, p. 36)

These specific rationalities, composing and connected in the Diagram of scientific literacy, almost exorcise the irrationalities of un-thought (the monstrous Becoming's) and reduce them to infinitesimal instances, their dark twins or monsters, so to speak (the BecomingOuroboros).

What is particular about the discursive formation of scientific literacy is a twin set of rationalities, which both structure and manifest upon the surface of the discursive formation. These rationalities are connected here to the image of the Ouroboros and are conceptualized as (1) the Helix, referring to the cyclical and spiral form progress of science and the eternal return of the Möbius strip, and (2) Momentum, referring to the continuous movement, unrest, and desire/appetite of science. These two rationalities are proposed as the necessary movements actualized within the concept of scientific literacy, movements revolving around a churning Abstract Machine dissolving itself and its creations, in a dynamic continuous genesis. In a Spinozist sense the two rationalities, and their movements, form the essence of scientific literacy, and it can thus be seen as a certain kind of extension of thought (the Helix) and a certain appetite to connect/reconnect bodies (Momentum), in this case knowledge.

There is a reason the depicted image of the Ouroboros (Fig. 1) is coiled like a Möbius strip: a dynamic is enveloped within these two rationalities, an empty square where the object $=\mathrm{x}$ resides, the paradoxical element that drives the Abstract Machine itself (Deleuze 2004a).

These rationalities are gathered in the Diagram of the Ouroboros to emphasize two things: (1) the intrinsic connection between specific Becomings and science (Deleuze and Guattari 1987) and (2) that these are a part of a pre-symbolical, almost mythological totemic becoming or dark side of Science and the Diagram and fresh Image of Thought of the Ouroboros help capture this aspect of scientific literacy. In other words, the rationalities 
Fig. 1 The Ouroboros by Anders Bang

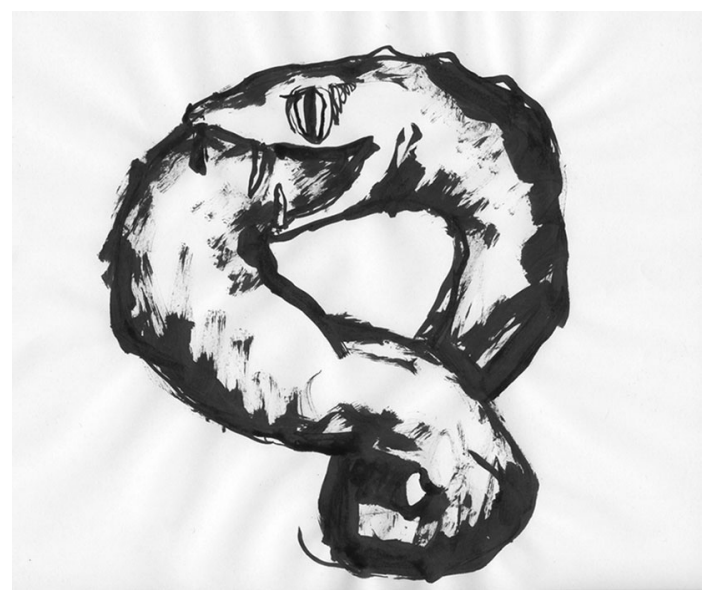

of Momentum and the Helix envelop a particular Abstract Machine within science that creates a dynamic movement here called ouroborossification, which, as a whole, threads together the discursive template of the Man of Science-consisting of the rationalities of the Helix and Momentum (and potentially related to other rationalities). Between the two rationalities of the machine is a differentiation between the Helix and Momentum, similar to Deleuze's use of $d y / d x$ (Deleuze 1994); there is a 'finite' infinity of multiplicities of actualized manifestations between these two rationalities. These rationalities are revealed in the respective analyses below (i.e. Spencer, Eliot, and PISA06) in their various manifestations.

The problematic of contemporary scientific literacy is especially connected to the workings of this Abstract Machine: Scientific Literacy has become too bloated, no longer destroying itself adequately, and is nearing a critical resting point. The Ouroboros thus functions as a Fresh Image of Thought (Deleuze 1994), revealing the intrinsic necessary conflict/essence within scientific literacy, opposing the dogmatic Image previously associated with scientific knowledge and scientific literacy.

To summarize, scientific literacy is an inadequate idea (Spinoza 1996) in the Spinozist sense, an inherently flawed concept that does not fully grasp the abstract machine coiled within. In other words, scientific literacy is a conceptual monstrum (Bang and Valero 2014) encased within a discursive formation. The vivisection and specific gaze applied here will overturn the concept, affirm it, and assemble it anew and show how it is connected to Becoming and the Diagram or the Abstract Machine of the Ouroboros. The conceptual monstrum is traced in Spencer, Eliot, and PISA06 and placed within the grid of its birth and transformations, that is, the topology of the Archive, the Map, and the Diagram. First, however, the gaze turns to an Archive of the present before carefully vivisecting the transformations of the Ouroboros and scientific literacy and locating shifts and turns. 


\section{The state of the present: a conflicted dichotomy in the concept of scientific literacy and its discursive formation}

In a contemporary conceptual analysis of the concept of scientific literacy Douglas A. Roberts emphasized two intrinsic but different visions connected to scientific literacy:

I shall argue that all of this diverse literature can be better understood if one comes to grips with a continuing political and intellectual tension that has always been inherent in science education itself. I refer to the role of two legitimate but potentially conflicting curriculum sources: science subject matter itself and situations in which science can legitimately be seen to play a role in other human affairs. (Roberts 2007, p. 729)

These two threads are the two magnetic poles in the discursive formation of Scientific Literacy, which, again, in the terms proposed here, is connected to the Diagram of the Ouroboros and the rationalities encircling it. Roberts (2007, p. 730) argued that they have become increasingly in conflict with each other:

That is, there seem to be two visions of [Scientific Literacy] that recently have come to represent the extremes on a continuum. I shall call them, simply, Vision I and Vision II, where a vision is much broader analytical category than, say, a definition.

These visions, or threads, in the discursive formation of Scientific Literacy are, of course, often entwined but, nevertheless, represent two completely different idealizations of scientific literacy:

Vision I gives meaning to [Scientific Literacy] by looking inward at the canon of orthodox natural science, that is, the products and processes of science itself. At the extreme, this approach envisions literacy (or, perhaps, thorough knowledgeability) within science.... Against that, Vision II derives its meaning from the character of situations with a scientific component, situations that students are likely to encounter as citizens. At the extreme, this vision can be called literacy (again read thorough knowledgeability) about science-related situations in which considerations other than science have an important place at the table. (Roberts 2007, p. 730, my emphasis)

Roberts' extensive analysis pointed out the contemporary effect and the state of the conflicted concept of scientific literacy. The two intrinsic visions, which Roberts constructed, however, cloak the problematic nature and thus the cause of such an inner relation. In short, they obfuscate the Diagram, the coiling Abstract Machine of the Ouroboros, which is the cause, and show only its skewed effect. The historical analysis outlined here shows how these visions, in their historical transformations and arbitrary origin, are ultimately opposed and incompossible. In other words, contemporary problems regarding scientific literacy can be traced through different transformations in the historical discursive formation, which gave arbitrary birth to the concept in the first place. The heuristic device of the two visions constructed by Roberts to explain the dichotomy and differences between scientific literacy and science literacy is thus not an arbitrary structure or simple device of rhetoric/argumentation, it represents a transformation of a historical unresolved dichotomy - an obfuscation of the Ouroboros.

Together with the Image of Thought of the Ouroboros and its intrinsic rationalities, this article traces the transformations of Roberts' binary of Vision, which is ultimately 
considered connected to the two rationalities of the Ouroboros, with Vision I connected to the ascendancy of the Helix inward looking/eating and Vision II connected to the ascendancy of Momentum gobbling up the world and enveloping it within Scientific Literacy. It is almost as if the Ouroboros has been sick since birth, from being either gluttonous and too fat or ascetic and too thin.

The skewed configuration between the two visions and the Ouroboros within is the result of this inadequate idea and conceptual monstrum of scientific literacy. There is, of course, an interchange, a function between the two visions, but one where the crucial derivate, the Becoming, of the function is overlooked. Vision I turn inwards toward science, restricting both the Momentum meaning that the Ouroboros becomes too narrow, too thin, ascetic and restricted. In Vision II, Scientific Literacy is turned outward/outside, in the extreme case straightening the Ouroboros, making it too hungry, incorporating too much knowledge, meaning that scientific literacy becomes too bloated and nearing a resting point. In other words, the schism between the two poles of Scientific Literacy is actualized in a manifested differentiation in the rationality of Man of Science. Two templates of desired utopian and Platonic templates of Being-Scientific are thus manifest and actualized: (1) an ascetic aristocratic Noble Science and (2) an ascetic Religious Scientism. Exemplified below in the cases of Spencer and Eliot. These templates of Being leave only infinitesimal space for minor Science, dark Science and monstrous Becoming's, and they become an overlooked derivate. Dark Science is here very much related to nonsense or socalled pseudo-science and magic; Deleuze and Guattari describes this as a constant relation and deterritorialization and reterritorialization between royal science and minor science (Deleuze and Guattari 1987), where one is continuously colonized by the other in a constant struggle. Royal science, the science acknowledged by the State, is the science deemed 'real' and proper within any given scientific community, minor science is that which is deemed to be pseudo-science and 'less real or probable'. Deleuze and Guattari write (1987, p. 368):

In any case, if the State always finds it necessary to repress the nomad and minor sciences, if it opposes vague essences and the operative geometry of the trait, it does so not because the content of these sciences is inexact or imperfect, or because of their magic or initiatory character, but because they imply a division of labor opposed to the norms of the State.

I propose that the derivate between these two relations or systems is actually dark Science, outcast from both domains (Bang 2015).

Eliot and Spencer acts as concrete cases or actualizations of these two different visions in their various discursive manifestations. The exact contemporary connection, or hybridization, of these two visions, their actualized templates, and the specific threading of the rationalities in the contemporary concept are the exposed problematic regarding the troublesome nature of scientific literacy. After this enunciation of the contemporary Ouroboros and problematic Visions I and II, the next section returns to the alleged father of scientific literacy, Herbert Spencer (1820-1903), and outline the arguments of the conclusions of Table 1 . 
Table 1 Configurations of the discursive formation of scientific literacy and the enveloped Ouroboros

\begin{tabular}{llll}
\hline Poles of scientific literacy & $\begin{array}{l}\text { Major aspect of the } \\
\text { abstract machine }\end{array}$ & $\begin{array}{l}\text { Minor aspect of the } \\
\text { abstract machine }\end{array}$ & The actualized rationality \\
\hline $\begin{array}{l}\text { Vision I (Noble Science) } \\
\text { Charles W. Eliot } \\
\begin{array}{l}\text { Vision II (Scientism) } \\
\text { Herbert Spencer }\end{array}\end{array}$ & The Helix & Momentum & $\begin{array}{r}\text { The Man of Science } \\
\text { (Aristocratic Asceticism) }\end{array}$ \\
\hline
\end{tabular}

\section{Herbert Spencer's template of being (scientism)}

There is a relationship between the thoughts of Charles W. Eliot (1834-1926) and Spencer, which was the main reason why Roberts (2007) historiography of scientific literacy mentioned them together. Eliot's introduction to the compilation of Spencer's essays acknowledged Spencer's great influence and impact on his contemporary effort to develop science education at Harvard (Spencer 2000). Spencer, overall, had a huge influence on contemporary thought. His contribution to bridging Darwin's thought to sociology and politics had especially widespread appeal (Elliott 2003). It is hard to overstate Spencer's influence and Roberts' pronouncement of him as the father of scientific literacy is well deserved.

One of Spencer's (Spencer 2000) most notable essays is 'What knowledge is of most worth', first written in 1859. It is a radical piece of work, as also noted by Eliot, and probably aimed to shake up the traditional view of education. One could summarize Spencer's work as an effort of scientism, since he viewed science as the basis for all decisions, running as the rational current behind all good human behaviour.

Spencer is thus posited as a clear voice, or discursive thread, of the manifestation of Vision II Roberts mentioned, a particularly skewed and misaligned Ouroboros (see Table 1). Spencer's approach, however, is so radical that Vision I had its arbitrary genesis at the same time Spencer's view and discursive formation took shape. In other words, it is suggested here that pure scientism created its own counter-discourse/recessive discourse, akin to Foucault's studies on pleasure and sex (Foucault 1992), which could explain why the discursive formation of scientific literacy and its transformations have since had their binary conflicted nature. Another way of understanding the relationship between Eliot and Spencer would be to posit an English influence of thought regarding education and morality towards a new American spirit of unity and reform after the US Civil War. Such an analysis, however, is not the focus here, but one can readily turn elsewhere to see the traces of such an investigation, see for instance Kieran Egan's analysis of the progressive inheritance from Herbert Spencer, John Dewey and Jean Piaget (Egan 2002) and David B. Tyack and Larry Cuban's analysis in their book Tinkering toward Utopia: a century of public school reform (Tyack and Cuban 1995).

The following exemplifies, enunciates, and vivisects how Spencer's statements create and actualize the specific rationality of the Man of Science (Bang 2014) and what was seen in later transformations as the reflective citizen or citizen science. This discursive formation is an earlier transformation of Vision II intrinsic in the contemporary conception of scientific literacy.

Spencer (1888, pp. 49-50) wrote: 
Lastly we have to assert - and the assertion will, we doubt not, cause extreme surprise - that the discipline of science is superior to that of our ordinary education, because of the religious culture that it gives. Of course we do not here use the words scientific and religious in their ordinary limited acceptations; but in their widest and highest acceptations. Doubtless, to the superstitions that pass under the name of religion, science is antagonistic; but not to the essential religion which these superstitions merely hide. Doubtless, too, in much of the science that is current, there is a pervading spirit of irreligion; but not in that true science which as passed beyond the superficial into the profound.... So far from science being irreligious, as many think, it is the neglect of science that is irreligious - it is the refusal to study the surrounding creation that is irreligious. [my emphasis]

This statement of Spencer is crucial in understanding how far his view extends science and the new manifestation of the rationality of the Man of Science and its specific configuration of the rationalities (the Helix and Momentum) within. In Spencer's discourse science becomes religion, the all-encompassing whole, and his true a priori is given in the laws of Nature, which becomes science, and upon this all other knowledge must be founded. The religious culture of science promoted here thus becomes all-encompassing and directly conflicts with the value of independence and truth, which only exist within the frame of Spencer's Nature/science. In other words, Spencer constructed and actualized, or added to, a specific rationality regarding the Man of Science related to Being-Scientific.

This ideal archetype, a part of the very frame of the discursive formation of scientific literacy, becomes the blueprint from which all pupils and education shall henceforth be judged. Spencer's Man of Science pursues with religious conviction investigations towards a specific scientific truth in conjunction with the laws set down by Nature itself. In other words, his rationality of the Man of Science becomes associated with asceticism and religiousness: 'By accumulated experiences the man of science acquires a thorough belief in the unchanging relations of the phenomena-in the invariable connexion of cause and consequence-in the necessity of good or evil results' (Spencer 2000, p. 51).

The above stands as a formulated scientific literacy in the nineteenth century, accumulated through experience, 'in the necessity of good or evil results':

Thus the question we set out with - What knowledge is of most worth? - the uniform reply is - Science. This is the verdict on all accounts.... We have not to estimate the degrees of importance of different orders of human activity, and different studies as severally fitting us for them; since we find that the study of Science, in the most comprehensive meaning, is the best preparation for all these orders of activity. (Spencer 2000, p. 53)

Science has, in Spencer, become the new altar, the new idol, to worship, believe in, and bow before. The next section returns to Eliot's position to enunciate the other pole in the discursive formation of scientific literacy and the other manifested and actualized template of Being-Scientific/Man of Science.

\section{Charles W. Eliot's template of Being (Noble Science)}

Eliot was president of Harvard from 1869 to 1909 and the drive and engine behind its transformation from a polytechnic college to an Ivy League institution and university (Katz 2009). Harvard became a blueprint and idealized model towards which other universities 
would strive (Hawkins 1972). In addition to universities and other tertiary forms of schooling, secondary schooling was similarly influenced by the new Harvard standard; thus Eliot's ideas and reforms were generally hailed through the American post-civil war education system as a whole (Tyack and Cuban 1995). The following enunciates, through the statements of Eliot, the specific kind of scientific/classical literacy he tried to promote, inspired by and in reaction to Spencer's ideas. Spencer and Eliot were never directly opposed in their views regarding scientific literacy but, rather, two shades of the same 'diagram of the outside of thought' regarding science and knowledge, simultaneously representing a new discursive formation in scientific literacy. In many ways, Eliot generally manifested and differentiated in the real institutions of America Spencer's actual ideas in the conditions of possibility in Harvard and American post-civil war schooling. There is, however, sufficient divergence between Eliot and Spencer, to argue for them being different proponents and poles of Scientific Literacy: one advocating the radical Vision II and the other the moderate Vision I, still contained within the same overall formation and thought of Scientific Literacy but actualizing two divergent templates of the Man of Science. Notably, one sees how Eliot draws upon the discursive formation of democracy in his discourse, far from Spencer's notions of democracy and visions of society in Man versus State (Spencer 1960).

Eliot's vision is well defined: there is a need for a demarcation between classical studies and scientific studies, especially in the polytechnic colleges. There is thus a similar demarcation between Eliot views of classical literacy and scientific literacy.

Eliot thus proposed a new organization, a new demarcation between the classical studies and science subjects in all educational institutions in the country. His task seemed to purify the befuddlement of education and to organize the various institutions into clearer lines of specialized study. Eliot's inaugural address at Harvard stressed this new demarcation (Eliot 1898, p. 3). This spirit of demarcation between the subjects, of organizing and specializing the students in their respective fields, imbues all of Eliot's writings and efforts in educational organization. There is an aristocratic asceticism, a noble ideal, and a rarefied belonging or elitism to education that should be fostered through a specific spirit of instruction promoting a specific kind of Being, actualized in Eliot's rationality of the Man of Science: 'A university keeps alive philosophy, poetry and science, and maintains ideal standards. It stands for plain living against luxury, in a community in which luxurious habits are constantly increasing and spreading' (Eliot 1901, p. 246).

Eliot's statements regarding democracy (Eliot 1901, p. 409) shows exactly how a discursive formation of democracy and a vision of the state entered his notion of education and scientific/classical literacy:

The vague desire for equality in a democracy has worked great mischief in democratic schools. There is no such thing as equality of gifts, or powers, or faculties, among either children or adults. On the contrary there is the utmost diversity.... The pretended democratic school is fighting not only against nature, but against the interests of democratic society.

One can thus see that Eliot's vision is intended to assimilate the individual spirit into its own diversity: 'Another important function of the public school in a democracy is the discovery and development of the gift or capacity of each individual child' (Eliot 1901, p. 408). It is notable how Eliot's vision resonates with modern and contemporary views of education and the overall statements regarding PISA06 (OECD 2007, p. 11).

Eliot (Eliot 1901, pp. 417-418) summarized and categorized all the above in the democratic nobility fostered within a democratic school: 
Finally, the democratic school must teach its children what the democratic nobility is. The well-trained child will read in history and poetry about patricians, nobles, aristocrats, princes, kings, and emperors, some of them truly noble, but many vile.... He will see what immense virtues these personal loyalties have developed, even when the objects of loyalty have been unworthy, and he will ask himself, 'What are to be the corresponding virtues in a democracy?' The answer is, Fidelty to all forms of duty.

Eliot's nobility becomes the template the State, as caretaker of the democratic school, should strive towards his specific enunciation of the Man of Science:

The children should learn that the democratic nobility exists, and must exist if democracy is to produce the highest types of character; but that it will consists only of men and women of noble character, produced under democratic conditions by the combined influences of fine inherited qualities, careful education and rich experience. (Eliot 1901, p. 418)

To summarize, Eliot's view of scientific literacy seems to be one of a pure demarcation and rarefaction that is to exist within a specific type of democratic school. One thus sees a connection to a discursive formation of democracy and how it has become enveloped within scientific/classical literacy, a notion of democracy that is anathema to Spencer's vision. Eliot referred to his vision as a liberal education (Eliot 1901, pp. 123-148) highlighting the virtue of liberty in education and similarly enunciated it as a particular vision for the State (where scientific literacy plays its specific role of enlightenment) in various statements: 'a university is in all countries a patriotic institution'(Eliot 1901, p. 247).

\section{The transformations of scientific literacy}

The two poles of the discursive formation of Scientific Literacy have been laid out and vivisected. These poles do not succeed or replace each other through different instances in time, but exist within the same discursive formation of scientific literacy. Eliot's Vision, manifested and actualized in his template of the Man of Science, is the one that has become the most manifested, most real, and most institutionalized, especially in America. Spencer's vision acts as a counter-discourse and shows its voice in discussions, writings, and curricula, especially in the United Kingdom, but also in the French and German positivism. Thus, when the emphasis on science and scientific literacy resurfaced in America and was later taken up in Europe, it was within that discursive formation frame-transformed, of course-but the inner intrinsic problematic of the Ouroboros still festers.

\section{The Ouroboros in the archive of PISA06}

The PISA06 is a manifestation and actualization of Scientific Literacy in an international survey and it is thus toward this fresh component of a new Archive that one turns to glimpse the Ouroboros in its discursive formation and its link to Democracy. The authors associated with the Organisation for Economic Co-operation and Development (OECD) and the designers of the framework clearly defined scientific literacy as follows: 
- Scientific knowledge and use of that knowledge to identify questions, acquire new knowledge, explain scientific phenomena and draw evidence-based conclusions about science-related issues

- Understanding of the characteristic features of science as a form of human knowledge and enquiry

- Awareness of how science and technology shape our material, intellectual, and cultural environments

- Willingness to engage in science-related issues and with the ideas of science, as a reflective citizen (OECD 2007, p. 23)

On the surface of the discursive formation of Scientific Literacy, Scientific literacy is thus connected to a specific set of competencies (using scientific knowledge, understanding, awareness, willingness) belonging to the 'reflective citizen'. This set of competencies is part of the idealized, almost Platonic mould of Being-Scientific. The OECD (2007) emphasized that the new concept of literacy has been expanded in the last two manifestations PISA2000 and PISA2003. In the new definition, the linkage between technology and science has been emphasized, as well as the role of science and society. In the OECD's clarification of the above definition, they explained the bullet point about willingness and the reflective citizen as follows:

The second part of the statement covers various aspects of attitudes and values that individuals may have towards science. The phrase implies a person who has an interest in scientific topics, thinks about science-related issues, has a concern for issues of technology, resources and the environment, and reflects on the importance of science in personal and social perspectives. (OECD 2007, p. 23)

The last statement reveals the discursive template of the reflective citizen, which is a citizen possessing scientific literacy. This citizen is, in a similar line of thought, dubbed 'citizen science', connecting science to practically every human endeavour and practice (Roth and Barton 2004, p. 9): 'It makes sense to conceive of scientific literacy in terms of "citizen science," which is "a form of science that relates in reflexive ways to the concerns, interests and activities of citizens as they go about their everyday business.",

The template and rationality of the reflective citizen/citizen science that is called the Man of Science here, in all its historical manifestations and transformations, is presupposed to be connected to democracy. This presupposition first showed its contemporary manifestation in the 1950s, see for instance Paul DeHart Hurd's paper on scientific literacy's role in American education (Hurd 1958) and E. R. Purpus' paper on the relation between scientific and technological literacy (Purpus 1954), but is similarly seen in countless historical manifestations and transformations dating back to Spencer's writings and beyond. In other words, there is a long, jagged historical linking between knowledge and democracy, of which the vivisection employed here exposes Eliot/Spencer and scientific literacy as a transformation, differentiation, and actualization of a specific Diagram of the Ouroboros.

The Ouroboros outlined in PISA06 is thus observable in at least one of its major rationalities, the Momentum, since Scientific Literacy is continuing to increase its scope, body of knowledge, and meaning. We can see how PISA06 continues to expand scientific literacy and what it should contain, when comparing it to the last two instances PISA2000 and PISA2003. Also, visible here is how the notion and thus the discursive formation of democracy becomes connected to scientific literacy. Scientific literacy as the pinnacle of reason of the epoch is connected to the pinnacle of a governance of reason-democracy. In 
other words, enlightenment, knowledge of nature and democracy are intrinsic to one another. This relation takes place through the persona and discursive template of the reflective citizen, a proper neoliberal citizen (Bazzul 2012), moulded as the Man of Science; in fact, they embody the unspoken presupposition between each other-the reflective citizen is needed for democracy and vice versa. There thus seems to be an implicit structural series of supposed causality and rationality in both directions:

$$
\text { Science education } \Leftrightarrow \text { scientific literacy } \Leftrightarrow \text { reflective citizen } \Leftrightarrow \text { democracy. }
$$

Seen from the other end of the series of linkages, science education and all that it entails could not exist without democracy. In other words, science and democracy fit together remarkably like hand and glove, in an intrinsic natural marriage.

\section{Wormholes to the present}

After examining and exposing the discursive formation of Scientific Literacy in three instances, two historic and one contemporary, one thus returns to the present problematic. This article has shown, through statements in PISA06, contemporary research in scientific literacy, and Spencer's and Eliot's writings, how democracy gets eaten by the Ouroboros and engulfed in the discursive formation of Scientific Literacy, which, from its arbitrary beginning, has been polarized regarding the Man of Science. In PISA06, the OECD and subsequent nation states are precisely testing to see if students have the adequate scientific knowledge and if they are within the desired template of the reflective citizen/citizen science, thus enacting a necessity, a natural link, between democracy and scientific Literacy. This is all done in the name of comparison, quality, and economic competitiveness. The Ouroboros have never been fatter and scientific literacy has turned toward Spencer's Vision II, but it has similarly devoured Vision I and engulfed it within a specific new capitalistic Scientism. Visions I and II thus exit side by side in the actualization of contemporary scientific literacy. The problematic poles no longer create the tension necessary for the dynamic of the Ouroboros and the Abstract Machine has almost reached a resting point. Science and its education, are in a resting point of misaligned ouroborossification, a specific form of calcification: scientific knowledge/literacy is no longer destroying itself and its connections, no longer constantly reordering itself and creating change. Science and scientific literacy have become the all-whole, a totality of encompassing thought, extended to infinity, engulfing everything.

Additionally, scientific literacy is travelling further and further down the educational system and has now become part of the kindergarten curriculum-all in the name of science, see for instance Helen Patrick et al.'s work (Patrick, Mantzicopoulos, and Samarapungavan 2009) or in the in the Benchmarks for scientific literacy published by the American Association for the Advancement of Science (AAAS 1993). The Ouroboros has become a perverse cybernetic worm, transformed through deterritorializations of capitalism. Because what banner does scientific literacy wave if not an economic one: an (economic) sustainable Earth, an (economic) productive climate, and a healthy (economic), extended life? Scientific literacy has become a vital component of the higher education arms race (Bang 2014), a cog in the machine to produce Being-Scientific and subsequently Being-Scientist, enunciating a specific rationality regarding the Man of Science. So hopefully the above leads one to the necessary conclusion: there is a need to overturn the Platonic ideals of Science, the Cogito in science education, and inadequate presuppositions 
and hopefully what has been outlined here can inspire educational researchers to look inward for the Ouroboros within science education with a fresh Image of Thought.

Acknowledgements This research was funded by Project-Youth-to-Youth, a regional educational project in Northern Jutland, Denmark. I would like to thank Professor Ingólfur Ásgeir Jóhanneson, University of Iceland and Kathrin Otrell-Cass, Aalborg University for helpful comments during the editing of the article. Additionally, I would like to thank the members of the Science and Mathematics Education Research Group (SMERG) and Center for Educational Research (CfU) at Aalborg University for their comments on previous drafts of this paper. This research is also part of the NordForsk Center of Excellence "JustEd".

Open Access This article is distributed under the terms of the Creative Commons Attribution 4.0 International License (http://creativecommons.org/licenses/by/4.0/), which permits unrestricted use, distribution, and reproduction in any medium, provided you give appropriate credit to the original author(s) and the source, provide a link to the Creative Commons license, and indicate if changes were made.

\section{References}

AAAS. (1993). Benchmarks for science literacy. London: Oxford University Press.

Bang, L. (2014). Welcome to school-Welcome to the Empire-Building Business: an exploration and expansion of Bourdieu's notion of field. Waikato Journal of Education, 19(1), 51-62.

Bang, L. (2015). The Logic of Science-A vivisection of monsters. Aalborg: Aalborg University Press.

Bang, L., \& Valero, P. (2014). Chasing the Chimera's Tails: An analysis of Interest in Science. In T. S. Popkewitz (Ed.), The "reason" of schooling. Historizing curriculum studies, pedagogy and teacher education. New York: Routledge.

Bazzul, J. (2012). Neoliberal ideology, global capitalism, and science education: engaging the question of subjectivity. Cultural Studies of Science Education, 7(4), 1001-1020.

Deleuze, G. (1986). Foucault (S. Hand, Trans. 2006 ed.). London: The Athlone Press.

Deleuze, G. (1994). Difference and repetition (P. Patton, Trans.). London: Continuum International Publishing Group.

Deleuze, G. (2004a). Desert Islands: And other texts, 1953-1974. New York: Semiotext.

Deleuze, G. (2004b). The method of dramatization. In D. Lapoujade (Ed.), Desert Island and other texts 1953-1974 (M. Taormina, Trans.). New York: Semiotext(e).

Deleuze, G., \& Guattari, F. (1983). Anti-Oedipus: capitalism and schizophrenia. Minneapolis: University of Minnesota Press.

Deleuze, G., \& Guattari, F. (1987). A thousand plateaus: capitalism and schizophrenia. Minneapolis: University of Minnesota Press.

Dreyfus, H. L., \& Rabinow, P. (1983). Michel Foucault: beyond structuralism and hermeneutics. Chicago: The University of Chicago Press.

Egan, K. (2002). Getting it wrong from the beginning: Our progressivist inheritance from Herbert Spencer, John Dewey, and Jean Piaget. London: Yale University Press.

Eliot, C. W. (1898). Inaugural address as president of Harvard College Educational reform: Esays and addresses (pp. 1-38). New York: The Century.

Eliot, C. W. (1901). Educational reform: Essays and addresses. New York: The Century co.

Elliott, P. (2003). Erasmus Darwin, Herbert Spencer, and the origins of the evolutionary worldview in British provincial scientific culture, 1770-1850. Isis, 94(1), 1-29.

Foucault, M. (1972). Archaeology of knowledge (A. M. S. Smith, Trans. 1st English ed.). London: Routledge.

Foucault, M. (1992). The use of pleasure (R. Hurley, Trans. Vol. 2). London: Penguin Books.

Foucault, M. (1995). Discipline and punish: The birth of the prison (A. Sheridan, Trans.). New York: Random House.

Hawkins, H. (1972). Between Harvard and America: The Educational Leadership of Charles W. Eliot. New York: Oxford University Press.

Hurd, P. D. (1958). Science literacy: Its meaning for American schools. Educational Leadership, 16(1), 13-16.

Hurd, P. D. (2002). Modernizing science education. Journal of Research in Science Teaching, 39(1), 3-9.

Jung, C. G. (1980). Psychology and alchemy. Collected works of C.G. Jung. Vol. 12 (R. Hull, Trans. 2 nd ed. Vol. 12.). New Jersey: Princeton University Press. 
Katz, M. B. (2009). Reconstructing American education. London: Harvard University Press.

Laugksch, R. C. (2000). Scientific literacy: A conceptual overview. Science Education, 84(1), 71-94.

Linder, C., Östman, L., Roberts, D. A., Wickman, P.-O., Ericksen, G., \& MacKinnon, A. (2010). Exploring the landscape of scientific literacy. New York: Routledge.

Lindsay, J. (1970). The origins of alchemy in Graeco-Roman Egypt. London: Barnes \& Noble.

Nietzsche, F. W. (2005). The anti-Christ, ecce homo, twilight of the idols: And other writings. Cambridge: Cambridge University Press.

OECD (2006). Evolution of student interest in science and technology studies. Policy report. Retrieved from Paris: http://www.oecd.org/science/sci-tech/36645825.pdf

OECD (2007). PISA 2006 science competencies for tomorrow's world volume 1-Analysis

Patrick, H., Mantzicopoulos, P., \& Samarapungavan, A. (2009). Motivation for learning science in kindergarten: Is there a gender gap and does integrated inquiry and literacy instruction make a difference. Journal of Research in Science Teaching, 46(2), 166-191.

Popkewitz, T. S. (2004). The Alchemy of the Mathematics Curriculum: Inscriptions and the Fabrication of the child. American Educational Research Journal, 41(1), 3-34.

Popkewitz, T. S. (2008). Cosmopolitanism and the age of school reform: Science, education, and making society by making the child. New York: Routledge.

Purpus, E. R. (1954). Scientific and technical literacy. The Journal of Higher Education, 25(9), 475-478.

Roberts, D. A. (2007). Scientific literacy/science literacy. In S. K. Abell \& N. G. Lederman (Eds.), Handbook of research on science education (pp. 729-780). New Jersey: Lawrence Erlbaum Associates Inc.

Roth, W.-M., \& Barton, A. C. (2004). Rethinking scientific literacy. London: Taylor and Francis Books Inc. Shamos, M. (1995). The myth of scientific literacy. New Jersey: Rutgers University Press.

Spencer, H. (1888). Education: Intellectual, moral, and physical. Chestnut Hill: Adamant Media Corporation.

Spencer, H. (1960). The man versus the state. Idaho: The Caxton Printers LTD.

Spencer, H. (2000). Education: Intellectual, moral, and physical. London: Adamant Media Corporation.

Spinoza, B. D. (1996). Ethics (E. Curley, Trans.). London: Penguin Group.

Tyack, D. B., \& Cuban, L. (1995). Tinkering toward utopia: A century of public school reform. Boston: Harvard University Press.

Wilson, M. D. (1995). Spinoza's theory of knowledge. In D. Garrett (Ed.), Cambridge companion to Spinoza. Cambridge: Cambridge University Press.

Dr. Lars Bang is a Research Fellow at Manchester Metropolitan University, Education and Social Research Institute, Faculty of Education, STEM Education. This article is related to the conceptual investigation and application in the Youth-to-Youth Project, an educational bridge-building project with a specific interest in science education. He has a background as a teacher in special education and holds a Master's degree in Education (Psychology). His current research and teaching interests include science education, educational research, history, and the philosophy of science. 